\title{
Anna Nadolska-Styczyńska
}

Uniwersytet Mikołaja Kopernika w Toruniu

Wydział Humanistyczny

Instytut Nauk o Kulturze

Katedra Etnologii i Antropologii Kulturowej

\section{Sprawozdanie z konferencji: Muzeum progresywne. Między utopią a rzeczywistością, Sopot, 10-11 października 2019 r.}

W dniach 10-11 października 2019 r. odbyła się w Sopocie ogólnopolska konferencja Muzeum progresywne. Między utopia a rzeczywistością. Jej organizatorami byli Grodzisko w Sopocie (oddział Muzeum Archeologicznego w Gdańsku) oraz Muzeum Sopotu.

Udział w konferencji wzięli muzealnicy — praktycy, ale także doświadczeni badacze kultury i zagadnień muzeologicznych z całej Polski. Zarówno liczne referaty (30) jak bardzo ożywiona dyskusja, która przenosiła się w kuluary, były dowodem wciąż aktualnej potrzeby prowadzenia interdyscyplinarnych dyskusji dotyczących problematyki muzealnictwa w Polsce. Ścierały się tutaj bowiem rozmaite postawy, doświadczenia, zderzały różne potrzeby i przekonania wynikające ze specyfiki poszczególnych dyscyplin reprezentowanych przez uczestników spotkania i rozmaitych sposobów prowadzenia jednostki przez jej kierownictwo.

Podczas tego dwudniowego spotkania rozważano zagadnienia podstawowe dla dzisiejszego muzealnictwa. Dotyczyły one bowiem tak podstaw prawnych działalności naszych muzeów, ich potrzeb merytorycznych oraz 
osiągnięć a także trudności w realizacji zamierzonych planów i problemów związanych z próbami przezwyciężania tych przeciwności.

Jednak podstawowym wątkiem było poszukiwanie wizji muzeum idealnego, nowoczesnego, zgodnego z oczekiwaniami współczesnej, wymagającej publiczności, ale realizującego swoje zadania instytucji ochraniającej dobra kultury. Starano się znaleźć odpowiedź na pytanie o istotę muzeum progresywnego i o możliwości realizacji w polskich realiach takiego modelu muzealnictwa. Zwracano uwagę i podkreślano etyczne problemy, jakie wywołują proponowane lub wprowadzane w muzealnictwie zmiany. Żywy odzew wywołały dyskusje poświęcone problemom prawnym: od dobrze znanych postulatów zastrzeżenia nazwy „muzeum” po przypadki naruszanie prawa autorskiego kuratorów i autorów scenariuszy do realizowanych wystaw, lekceważenia dorobku i doświadczenia pracowników. Omawiano także potrzeby oraz prawa przypisane publiczności. Zwracano uwagę na polityczne uwikłania muzeów i szkody, jakie to powoduje w ich działaniach merytorycznych — tak ochronnych, jak edukatorskich.

Stawiano pytania o istotę muzeum, o miejsce publiczności w kształtowaniu jego misji i działalności, o potrzebę stawiania zadań ponad dzisiejsze możliwości, jako punktu wyjścia na drodze do rozwoju. Ważnym wątkiem okazało się poszukiwanie miejsca, jakie muzea mają zajmować pośród innych instytucji kultury. Na ile ma być ono miejscem adresowanej do wszystkich chętnych rozrywki i sposobem spędzenia wolnego czasu, a na ile pozostać muzeum — świątynią czy muzeum — agorą, skupiającym osoby zainteresowane utrzymaniem jego tożsamości merytorycznej.

Organizatorzy umożliwili uczestnikom podjęcie próby wspólnego stworzenia modelu muzeum progresywnego/idealnego, poprzez dopisywanie na zamieszczonej w sali planszy kolejnych cech takiej placówki.

Powinna być to zatem:

- instytucja, która uznaje proces rozwoju za przeciwieństwo trwania w nawet najbardziej pożądanym stanie,

- instytucja działająca na rzecz ochrony dziedzictwa (materialnego i niematerialnego),

- instytucja twórczo współpracująca z innymi instytucjami, dzieląca się swoimi doświadczeniami i zbiorami,

- instytucja etyczna, realizująca w swych działaniach kategorię prawdy,

- instytucja zarządzana humanistycznie, w której człowiek jest podmiotem, a nie przedmiotem działań, 
— instytucja, w której pracownicy są najważniejszym i najcenniejszym zasobem muzeum,

— instytucja, prowadząca stały dialog z publicznością.

- muzeum progresywne - instytucją dobra wspólnego.

Bardzo istotne było uporządkowanie tematyczne poszczególnych bloków konferencji. Po pierwszym, wstępnym wystąpieniu organizatora i gospodarza - Krzysztofa Godona, omawiającym genezę i zakres działań nietypowej placówki, jakim jest Grodzisko w Sopocie, nastąpiły referaty dotyczące zagadnień ogólnych: prawnych, organizacyjnych, tożsamościowych, miejsca, jakie muzea zajmują w środowisku lokalnym itd. Blok II dotyczył muzeów etnograficznych. Ich specyfice i przemian w działalności oraz ich problemów w znalezieniu własnego „klucza” do ochrony i prezentowania kultury. Wspólnym mianownikiem referatów bloku III były organizacja, rozwój i zarządzanie muzeum. Dyskusję dnia pierwszego podsumowało otwarte forum: Muzeum - między przeszłością a przyszłością: wyzwania, dylematy, szansa, prowadzone przez prof. dr. hab. Cezarego Obracht-Prondzyńskiego. Kolejny dzień konferencji rozpoczął blok poświęcony blaskom i cieniom wykorzystywania w muzealnictwie multimediów oraz problematyce ekspozycji. Zakończony on został wystąpieniem opartym na doświadczeniach Europejskiego Centrum Solidarności, omawiającym zjawisko możliwości pojawiania się wyjątkowej aktywności „sfery obywatelskiej” w sytuacji zagrożenia istnienia lub/i działalności instytucji kultury.

Kolejny blok, dotyczący placówek o rozmaitym zakresie tematycznym i organizacyjnym, zawierał wystąpienia omawiające potrzeby i oczekiwania dotyczące polskiego muzealnictwa. Obfitował zarówno w wystąpienia o charakterze teoretycznym, postulującym pewne rozwiązania o charakterze ogólnym, dotyczące potrzeby i kierunku planowanych lub tylko rozważanych przemian, jak i przykłady konkretnych działań, planów powstania nowych i rozbudowy istniejących już muzeów.

Ostatni blok, będący de facto kontynuacją tych wątków, pozwolił na poznanie poglądów i doświadczeń badaczy i muzealników dotyczących m.in. przekładania się polityki i konfliktów na linii organizator — muzeum, ale także problemów zewnętrznych, na możliwości realizacji zadań placówek muzealnych. Zakończył go natomiast referat ukazujący zakresy i ścieżki prowadzenia współpracy jednostki z „organizatorami” muzeów, na przykładzie Muzeum Miejskiego w Żorach. Uzupełniony on został posłowiem, 
podkreślającym, że wiele problemów, z którymi się polskie muzea borykają, a które utrudniają im rozwój zgodny z oczekiwaniami organizatorów czy pracowników, bledną w obliczu zagrożeń wojennych, jakie dotykają instytucje istniejące na terenie Afryki. Tam podstawowym problemem staje się przetrwanie.

Ostatnim punktem spotkania była dyskusja podsumowująca, prowadzona przez dr hab. Dorotę Folgę-Januszewską. Konferencja wskazała potrzebę ciągłego rozwoju polskiego muzealnictwa, zgodnie z najnowszymi trendami i postulatami wypracowanymi przez ICOM, zgodnie z prawem, etyką i zdrowym rozsądkiem. Udowodniła także po raz kolejny, że zaczynać trzeba od marzeń. Nawet tych na pierwszy rzut oka niemożliwych do realizacji. 